\title{
Keefektivan Padi Transgenik terhadap Hama Penggerek Batang Padi Kuning Scirpophaga incertulas (Walker) (Lepidoptera: Crambidae)
}

\author{
N. USYATI ${ }^{1)}$, DAMAYANTI BUCHORI ${ }^{2)}$, SYAFRIDA MANUWOTO ${ }^{2)}$, \\ PURNAMA HIDAYAT ${ }^{2)}$, INEZ H. SLAMET-LOEDIN ${ }^{2)}$ \\ ${ }^{1)}$ Balai Besar Penelitian Tanaman Padi \\ ${ }^{2)}$ Departemen Proteksi Tanaman, Institut Pertanian Bogor \\ (diterima November 2008, disetujui Februari 2009)
}

\begin{abstract}
Effectiveness of Transgenic Rice to The Rice Yellow Stemborer Scirpophaga incertulas (Walker) (Lepidoptera: Crambidae). Transformation two cry genes (cryIB-cryIAa) and transformation with a single the $c r y 1 \mathrm{~B}$ gene under the control of a wound-inducible maize proteinase inhibitor gene (mpi) promoter were two approaches that were used to get resistant rice to the rice stemborer which may be had a durable resistance. To obtain information on the effectiveness of seven transgenic rice lines to the rice yellow stemborer $S$. incertulas, a test was conducted in greenhouse. The seven lines were 1). line 4.2.3 and 2) line 4.2.4 both contain fusion of two cry genes (cryIB-cryIAa); 3) line 3R9 and 4) line 3R7 lines both contain of mpi-cry IB gene; and 5) line 6.11 contains of cryIAb gene by particle bombardment, 6) line DT-cry (Azygous) that do not contain cry gene (null), and 7) DT-cry line contains cryIAb gene by Agrobacterium, and as a negative control, we used three non transgenic rice varieties i.e., Rojolele, Cilosari, and Ciherang. The result showed that transgenic rice lines, except DT-cry and DT-cry (Azygous) lines were effective to suppress damage by the insect, and showed an inhibition effect on the growth of $S$. incertulas, and had a high level ofresistance than non transgenic rice varieties had. There were differences on resistance value/level among transgenic rice lines. Based on the resistance value, 6.11 line was the highest (scale 0) followed by 4.2.4 line and 3R7 line, these lines were categorized as high resistance (scale 1). Transgenic rice-4.2.3 line and 3R9 line were categorized as moderat resistance (scale 3). DT-cry and DT-cry (Azygous) lines were susceptible (scale 7-9).
\end{abstract}

KEY WORDS: Effectiveness, resistance value, transgenic rice, $S$. incertulas

\section{PENDAHULUAN}

Dengan berkembangnya teknologi rekombinan DNA telah membuka pintu untuk merakit tanaman tahan hama dengan rekayasa genetika. Teknologi ini mempunyai beberapa kelebihan jika dibandingkan dengan teknologi konvensional, yaitu (1) memperluas pengadaan sumber gen resistensi karena dengan teknologi ini 
kita dapat menggunakan gen resisten dari berbagai sumber, tidak hanya dari tanaman dalam satu spesies tetapi juga dari tanaman yang berbeda spesies, genus atau famili, dari bakteri, fungi, dan mikroorganisme lain, (2) dapat memindahkan gen spesifik ke lokasi yang spesifik pula di tanaman, (3) dapat menelusuri stabilitas gen yang dipindahkan atau yang diintroduksi ke tanaman dalam setiap generasi tanaman, (4) dapat mengintroduksi beberapa gen tertentu dalam satu event transformasi sehingga dapat memperpendek waktu perakitan tanaman multiple resistant, dan (5) perilaku gen yang diintroduksi di dalam lingkungan tertentu dapat diikuti dan dipelajari, seperti kemampuan gen tersebut di dalam tanaman tertentu untuk pindah ke tanaman lain yang berbeda spesiesnya (outcrossing), dan dampak negatif dari gen tersebut di dalam tanaman tertentu terhadap lingkungan dan organisme bukan target (Bahagiawati 2001). Namun seperti halnya hasil pemuliaan konvensional, ketahanan tanaman transgenik dapat dipatahkan. Ho et al. (2006) melaporkan beberapa populasi serangga telah berkembang resisten terhadap gen $c r y$ tunggal.

Untuk managemen resistensi, Cohen (2000) menganjurkan untuk menggunakan strategi "high-dose" dan refugia, serta menganjurkan untuk mengembangkan tanaman dengan dua toxin $B t$, karena kultivar dengan dua toxin memerlukan refugia paling kecil dan memungkinkan untuk dilepas di lapangan. Penggunaan gen multipletoxin dengan cara kerja yang berbeda juga dianjurkan sehingga crossresistance tidak mungkin terjadi, yaitu dengan menggunakan dua gen cry untuk toxin yang berbeda reseptor atau kombinasi gen cry yang semuanya berbeda dan tidak berkaitan gen toxinnya (Ho et al. 2006).

Efikasi dari fusi hibrid gen cry1Ab-cryIAc pada padi transgenik indica telah berhasil diuji pada kondisi rumah kaca (Wu et al. 1997; Datta et al. 1998), dan hasilnya menunjukkan mampu melindungi serangan penggerek batang padi kuning. Padi transgenik Bt-IR72 dengan fusi gen ini menunjukkan konsisten tahan melawan empat serangga lepidoptera, termasuk penggerek batang padi kuning lebih dari 3 generasi di bawah kondisi serangan secara buatan dan alami (Ye et al. 2001). Sementara Ho et al. (2006) melaporkan bahwa fusi dua gen cry (cryIAb-IB) pada kultivar padi transgenik elit Vietnam mampu mematikan $100 \%$ larva instar-1 penggerek batang padi kuning dalam 1 minggu setelah infestasi.

Di Indonesia, upaya untuk mendapatkan padi tahan penggerek batang padi yang memiliki ketahanan panjang (tidak mudah patah) telah dilakukan dengan 2 pendekatan yaitu: (1) transformasi dua gen cry (cryIBcryIAa) yang berbeda binding site 
dalam sistem pencernaan larva serangga, dan (2) transformasi gen cryIB dibawah kendali promoter terinduksi pelukaan yaitu promoter dari gen maize proteinase inhibitor (mpi). Dari hasil penelitian pada tahun 2003 dan 2004 pada generasi pertama dan kedua, telah diperoleh 2 galur padi transgenik cv. Rojolele mengandung fusi dua gen cry (cryIB-cryIAa) dan 4 galur padi transgenik cv. Rojolele mengandung gen mpi-cryIB (Rahmawati 2004). Namun demikian, efektivitas galur-galur tersebut terhadap penggerek batang padi kuning $S$. incertulas belum teruji di rumah kaca. Penelitian ini bertujuan untuk mendapatkan informasi mengenai tingkat efektivitas padi transgenik terhadap hama penggerek batang padi kuning $S$. incertulas di rumah kaca.

\section{BAHAN DAN METODE}

\section{Waktu dan Tempat}

Penelitian dilakukan di Rumah Kaca Khusus Padi Transgenik (Biosafety Containment), Pusat Penelitian Bioteknologi - LIPI, Cibinong-Bogor pada bulan April September 2008.

\section{Bahan dan Alat}

Serangga uji yang digunakan dalam penelitian ini adalah penggerek batang padi kuning $S$. incertulas. Imago $S$. incertulas diambil dari pertanaman padi di Kecamatan Ciasem, Kabupaten Subang, Jawa
Barat. Selanjutnya imago $S$. incertulas dipelihara pada tanaman padi varietas Ciherang di rumah kaca Balai Besar Penelitian Tanaman Padi SukamandiSubang sampai bertelur. Kelompok telur yang dihasilkan selanjutnya diambil dan dimasukkan ke dalam tabung gelas untuk dipelihara sampai menetas menjadi larva instar-1. Larva instar-1 ini yang digunakan untuk pengujian.

Materi penelitian yang digunakan terdiri atas 7 galur padi transgenik, yaitu galur 4.2.3 dan 4.2.4 yang mengandung fusi dua gen cry (cryIBcryIAa), galur 3R9 dan 3R7 yang mengandung gen mpi-cryIB, galur 6.11 yang mengandung gen cryIAb melalui teknik penembakan, galur DTcry (Azygous) yang ikut dalam transformasi tetapi negatif cry (null), dan galur DT-cry yang mengandung gen cryIAb melalui Agrobacterium, serta tanaman padi bukan transgenik yang meliputi varietas Rojolele, Cilosari, dan Ciherang.

Untuk mendeteksi keberadaan gen pada tanaman padi transgenik yang diuji, dilakukan uji PCR. Tanamantanaman yang berdasarkan uji PCR memberikan hasil positif selanjutnya digunakan untuk pengujian, sementara tanaman-tanaman yang berdasarkan uji PCR hasilnya negatif dibuang.

\section{Metode Penelitian}

$\begin{array}{ccr}\text { Penelitian } & \text { dilakukan } & \text { dengan } \\ \text { rancangan } & \text { acak } \\ \text { elompok }(\mathrm{RAK}) & \text { dengan } 10 \text { perlakuan }\end{array}$


dan 10 ulangan. Perlakuan meliputi: A = galur 4.2 .3 (fusi), $\mathrm{B}=$ galur 4.2.4 (fusi), $\mathrm{C}=$ galur 3R9 (mpi), $\mathrm{D}=$ galur 3R7 (mpi), $\mathrm{E}=$ galur 6.11 (cryIAb$\mathrm{PB}), \mathrm{F}=$ galur DT-cry (Azygous), $\mathrm{G}=$ galur DT-cry (cryIAb-Agr), $\mathrm{H}=$ varietas Rojolele, $\mathrm{I}=$ varietas Cilosari, dan $\mathbf{J}=$ varietas Ciherang.

Uji ketahanan terhadap serangga dilakukan dengan menggunakan metode seperti yang dikemukakan oleh Heinrich et al. (1985). Tahap-tahap uji ketahanan adalah sebagai berikut: bibit padi berumur 21 hari di tanam di dalam pot sebanyak 1 bibit per pot. Masing-masing galur dan varietas padi ditanam 10 pot dan 1 pot dianggap 1 ulangan. Pot tersebut kemudian diatur dalam tata letak yang mengikuti rancangan acak kelompok. Tanaman padi dikurung dalam kurungan plastik milar segera setelah tanam untuk menghindari serangga lain di area pengujian. Pada umur 45 hari setelah sebar, tanaman padi diberi larva instar$1 S$. incertulas dengan kepadatan 3 larva per 1 anakan. Larva ditempatkan di dekat aurikel daun termuda dan pot ditutup atau dikurung dengan kurungan plastik milar untuk mencegah perpindahan larva antar pot. Persentase sundep untuk masingmasing galur dihitung pada 2 dan 4 minggu setelah infestasi larva menggunakan formula berikut:

Jumlah sundep pada galur yang diamati

Serangan sundep = ------------------ X 100\%

Jumlah anakan dari galur yang sama
Persentase sundep tersebut dikonversikan ke dalam nilai D sebagai berikut:

$\mathrm{D}=\frac{\text { \% sundep dari galur yang diuji }}{\text { \% sundep dari varietas pembanding rentan }}$

Nilai D ditransformasikan ke dalam skala $0-9(0=0 \% ; 1=1-20 \% ; 3$ $=21-40 \% ; \quad 5=41-60 \% ; 7=61-80 \%$; $9=81-100 \%)$. Tanaman tahan adalah tanaman yang mempunyai nilai $\mathrm{D} 0,1$, 3 , atau 5, sedangkan tanaman rentan mempunyai nilai D 7 atau 9.

Pada 4 minggu setelah infestasi (MSI), tanaman padi yang diuji pada satu ulangan yang sama sebanyak 1 tanaman per ulangan dibelah untuk mengetahui perkembangan larva. Variabel yang diukur adalah bobot basah pupa.

Data yang diperoleh dianalisis dengan analisis sidik ragam (ANOVA) dan perbedaan antar perlakuan dievaluasi dengan uji wilayah berganda Duncan pada taraf nyata 5\% dengan menggunakan program SAS (1990).

\section{HASIL DAN PEMBAHASAN}

Tanaman padi transgenik terbukti mempunyai kemampuan untuk menangkal kerusakan yang disebabkan oleh hama penggerek batang padi kuning $S$. incertulas. Hal ini dapat terlihat dari hasil pengamatan pengujian ini pada 2 dan 4 minggu setelah infestasi. 
Pada 2 minggu setelah infestasi, intensitas serangan $S$. incertulas pada semua galur padi transgenik yang diuji nyata lebih rendah dibandingkan dengan padi bukan transgenik varietas Rojolele dan Ciherang, serta galur DTcry (Azygous) $\quad(\mathrm{P}=0.0001)$. Berdasarkan nilai $\mathrm{D}$, pada pengamatan 2 minggu setelah infestasi terlihat bahwa semua galur padi transgenik yang diuji masuk dalam kategori tahan dengan skala 0-3 kecuali galur DT Cry-(Azygous) (Tabel 1). Pada 4 minggu setelah infestasi, intensitas serangan $S$. incertulas pada semua galur padi transgenik yang diuji, kecuali galur DT-cry dan DT-cry (Azygous), nyata lebih rendah dibandingkan dengan varietas padi bukan transgenik $(\mathrm{P}=0.0001)$. Berdasarkan nilai $\mathrm{D}$, pada pengamatan 4 minggu setelah infestasi terlihat bahwa semua galur padi transgenik yang diuji masuk dalam kategori tahan dengan skala 0-3. kecuali galur DTcry dan DT-cry (Azygous) masuk kategori rentan dengan nilai ketahanan masing-masing pada skala 7 dan 9 (Tabel 2).

Tanaman padi transgenik selain mempunyai kemampuan untuk menangkal kerusakan juga mempunyai kemampuan untuk menghambat pertumbuhan hama $S$. incertulas. Hal ini terbukti pada semua galur padi transgenik yang diuji tidak ada satu pun $S$. incertulas yang mencapai stadium pupa. Sebaliknya pada semua tanaman padi bukan transgenik, $S$. incertulas mampu mencapai stadium pupa dengan bobot pupa berkisar 0,01-0,02 gram (Tabel 3 dan Gambar $1)$.

Tabel 1. Rata-rata intensitas serangan $S$. incertulas pada 2 minggu setelah infestasi dan nilai ketahanan tanaman padi pada berbagai perlakuan

\begin{tabular}{lcrrr}
\hline \multicolumn{1}{c}{ Perlakuan } & $\begin{array}{c}\text { Rata-rata intensitas serangan } \pm \text { SE } \\
(\%)\end{array}$ & Nilai D & Skala & Ketahanan \\
\hline Galur 4.2.3 (fusi) & $20,00 \pm 8,17 \mathrm{cde}$ & 25,81 & 3 & $\mathrm{~T}$ \\
Galur 4.2.4 (fusi) & $23,33 \pm 7,93 \mathrm{~cd}$ & 30,10 & 3 & $\mathrm{~T}$ \\
Galur 3R9 (mpi) & $15,00 \pm 7,64 \mathrm{de}$ & 19,35 & 1 & $\mathrm{~T}$ \\
Galur 3R7 (mpi) & $15,00 \pm 7,64 \mathrm{de}$ & 19,35 & 1 & $\mathrm{~T}$ \\
Galur 6.11 & $0,00 \pm 0,00 \mathrm{e}$ & 0,00 & 0 & $\mathrm{~T}$ \\
Galur DT cry-Azygous & $60,83 \pm 9,47 \mathrm{ab}$ & 29,03 & 3 & $\mathrm{R}$ \\
Galur DT- cry & $22,50 \pm 6,58 \mathrm{~cd}$ & 103,23 & 9 & $\mathrm{~T}$ \\
Rojolele & $80,00 \pm 8,17 \mathrm{a}$ & 59,14 & 5 & $\mathrm{~T}$ \\
Cilosari & $45,83 \pm 11,33 \mathrm{bc}$ & 100,00 & 9 & $\mathrm{R}$ \\
Ciherang & $77,50 \pm 7,03 \mathrm{a}$ & & & \\
${ }^{*}$ Angka yang diikuti oleh huruf yang sama pada kolom yang sama pada masing-masing perlakuan tidak \\
berbeda nyata pada DMRT taraf nyata $5 \%$ T $=$ Tahan, R= Rentan
\end{tabular}


Tabel 2. Rata-rata intensitas serangan $S$. incertulas pada 4 minggu setelah infestasi dan nilai ketahanan tanaman padi pada berbagai perlakuan

\begin{tabular}{lcrrr}
\hline \hline \multicolumn{1}{c}{ Perlakuan } & $\begin{array}{c}\text { Rata-rata intensitas serangan } \pm \text { SE } \\
(\%)\end{array}$ & Nilai D & Skala & Ketahanan \\
\hline Galur 4.2.3 (fusi) & $18,33 \pm 7,64 \mathrm{~b}$ & 28,58 & 3 & $\mathrm{~T}$ \\
Galur 4.2.4 (fusi) & $6,67 \pm 4,44 \mathrm{bc}$ & 10,40 & 1 & $\mathrm{~T}$ \\
Galur 3R9 (mpi) & $20,00 \pm 10,18 \mathrm{~b}$ & 31,19 & 3 & $\mathrm{~T}$ \\
Galur 3R7 (mpi) & $11,67 \pm 6,11 \mathrm{bc}$ & 18,20 & 1 & $\mathrm{~T}$ \\
Galur 6.11 & $0,00 \pm 0,00 \mathrm{c}$ & 0,00 & 0 & $\mathrm{~T}$ \\
Galur DT cry-Azygous & $60,33 \pm 5,05 \mathrm{a}$ & 94,07 & 9 & $\mathrm{R}$ \\
Galur DT- cry & $45,83 \pm 7,58 \mathrm{a}$ & 71,46 & 7 & $\mathrm{R}$ \\
Rojolele & $65,67 \pm 7,76 \mathrm{a}$ & 102,40 & 9 & $\mathrm{R}$ \\
Cilosari & $49,33 \pm 11,49 \mathrm{a}$ & 76,92 & 7 & $\mathrm{R}$ \\
Ciherang & $64,13 \pm 6,91 \mathrm{a}$ & 100,00 & 9 & $\mathrm{R}$ \\
\hline
\end{tabular}

*) Angka yang diikuti oleh huruf yang sama pada kolom yang sama pada masing-masing perlakuan tidak berbeda nyata pada DMRT taraf nyata $5 \%$. T $=$ Tahan, $\mathrm{R}=$ Rentan

Tabel 3. Rata-rata bobot pupa $S$. incertulas pada 4 minggu setelah infestasi pada berbagai perlakuan

\begin{tabular}{lc}
\hline \hline \multicolumn{1}{c}{ Perlakuan } & Rata-rata bobot pupa $\pm \mathrm{SE}$ (gram) ${ }^{*}$ \\
\hline Galur 4.2.3 (fusi) & $0,00 \pm 0,00 \mathrm{c}$ \\
Galur 4.2.4 (fusi) & $0,00 \pm 0,00 \mathrm{c}$ \\
Galur 3R9 (mpi) & $0,00 \pm 0,00 \mathrm{c}$ \\
Galur 3R7 (mpi) & $0,00 \pm 0,00 \mathrm{c}$ \\
Galur 6.11 & $0,00 \pm 0,00 \mathrm{c}$ \\
Galur DT cry-Azygous & $0,02 \pm 0,01 \mathrm{ab}$ \\
Galur DT cry & $0,00 \pm 0,00 \mathrm{c}$ \\
Rojolele & $0,02 \pm 0,01 \mathrm{a}$ \\
Cilosari & $0,01 \pm 0,01 \mathrm{bc}$ \\
Ciherang & $0,02 \pm 0,01 \mathrm{ab}$ \\
\hline
\end{tabular}

*) Angka yang diikuti oleh huruf yang sama pada kolom yang sama pada masing-masing perlakuan tidak berbeda nyata pada DMRT taraf nyata $5 \%$
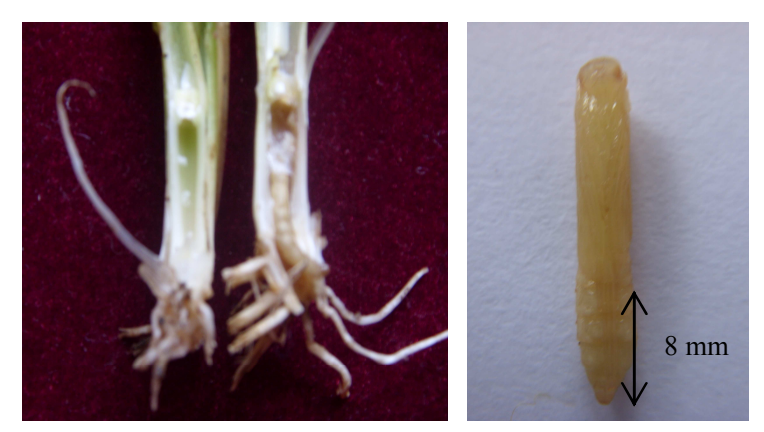

Gambar 1. Pupa S. incertulas pada tanaman padi bukan transgenik. [cam:digital] 
Berdasarkan hasil pengujian pada tahap ini menunjukkan bahwa semua galur padi transgenik yang diuji, kecuali galur DT-cry dan DT-cry (Azygous), lebih efektif dalam menangkal kerusakan dan menghambat pertumbuhan hama $S$. incertulas serta mempunyai nilai ketahanan yang tinggi dibandingkan dengan varietas padi bukan transgenik. Hal ini disebabkan oleh sumber ketahanan intrinsik yang berbeda antara padi transgenik dan padi bukan transgenik. Sumber ketahanan intrinsik pada padi transgenik adalah toxin yang berasal dari gen cryIAb, fusi dua gen cry (cryIB-cryIAa), dan gen mpi-cryIB. Sumber ketahanan intrinsik pada padi bukan transgenik umumnya berasal dari karakteristik biokimia dan karakteristik biofisik tanaman yang mempengaruhi perilaku atau metabolisme serangga (Kogan 1982).

Selain itu, pada pengujian tahap ini terlihat ada perbedaan nilai ketahanan antar galur padi transgenik. Menurut Schuler (2000) tingkat ketahanan tanaman terhadap hama target tergantung pada tingkat ekspresi dari transgen, sifat toksisitas dari protein yang disandi oleh transgen, dan kerentanan serangga hama target. Padi transgenik galur 6.11 mempunyai nilai ketahanan tertinggi dengan skala 0 , hal ini disebabkan galur 6.11 mengandung gen cryIAb dengan promoter yang bersifat constitutive. Tanaman transgenik dengan kontrol ekspresi gen seperti ini, gennya akan terekspresi terus menerus diseluruh jaringan tanaman dan sepanjang umur tanaman. Dengan demikian tanaman akan mendapat perlindungan sepanjang umur tanaman tersebut (Datta et al.1998; Fontes et al. 2002). Selain itu, galur 6.11 mempunyai toksisitas yang sangat tinggi. Hal ini terbukti pada pengamatan jumlah serangga yang mati vitro yang menunjukkan bahwa mortalitas $50 \%$ larva instar- $1 S$. incertulas pada galur 6.11 tercapai dalam waktu 12 jam setelah infestasi dan pada 72 jam setelah infestasi mortalitasnya mencapai 94\%.

Padi transgenik galur 4.2 .4 (fusi) dan 3R7 (mpi) mempunyai nilai ketahanan pada skala 1 . Hal ini disebabkan galur 4.2.4 (fusi) mengandung dua gen cry yaitu cryIAacryIB yang mempunyai binding site berbeda dengan promoter yang bersifat constitutive. Tanaman transgenik dengan kontrol ekspresi gen seperti ini, gennya akan terekspresi terus menerus diseluruh jaringan tanaman dan sepanjang umur tanaman. Dengan demikian tanaman akan mendapat perlindungan sepanjang umur tanaman tersebut (Datta et al, 1998; Fontes et al. 2002). Selain itu, galur 4.2.4 (fusi) mempunyai toksisitas yang tinggi setelah galur 6.11. Hal ini terbukti pada pengamatan mortalitas serangga yang dilakukan pada cawan petri yang menunjukkan bahwa mortalitas 50\% 
larva instar-1 $S$. incertulas pada galur 4.2 .4 (fusi) tercapai dalam waktu 24 jam setelah infestasi dan pada 72 jam setelah infestasi mortalitasnya mencapai 89\% (Usyati et al, 2010 in press)

Padi transgenik galur 3R7 (mpi) mengandung gen mpi-cryIB dengan promoter maize proteinase inhibitor yang bersifat inducible. Tanaman transgenik dengan kontrol ekspresi gen seperti ini, gennya hanya akan terekspresi apabila ada gigitan serangga. Selain itu, galur 3R7 (mpi) mempunyai toksisitas yang tinggi setelah galur 6.11 dan galur 4.2.4 (fusi). Hal ini terbukti pada pengujian mortalitas serangga di cawan petri yang menunjukkan bahwa mortalitas $50 \%$ larva instar-1 S. incertulas pada galur 3R7 (mpi) tercapai dalam waktu 12 jam setelah infestasi dan pada 72 jam setelah infestasi mortalitasnya mencapai 78\% (Usyati et al, 2010 in press).

Selain faktor kontrol ekspresi gen dan toksisitas yang menyebabkan padi transgenik galur 6.11, galur 4.2.4 (fusi) dan galur 3R7 (mpi) mempunyai nilai ketahanan tinggi, faktor jumlah salinan gen (copy number) juga turut berperan. Padi transgenik galur 6.11, galur 4.2.4 (fusi) dan galur 3R7 (mpi) mempunyai jumlah salinan gen (copy number) cukup banyak (Tabel 4). Dengan jumlah salinan gen (copy number) yang banyak tersebut kemungkinan ekspresi protein menjadi lebih tinggi. Jumlah salinan gen (copy number) pada beberapa kasus berkorelasi dengan ekspresi gen, meskipun tidak selalu demikian.

Padi transgenik galur 4.2 .3 (fusi) dan galur 3R9 (mpi) mempunyai nilai ketahanan pada skala 3. Hal ini diduga disebabkan gennya kurang terekspresi karena situs insersi gen kurang tepat dalam genom tanaman. Menurut Satoto (2003) ekspresi transgen yang dicerminkan oleh tingkat ketahanan diduga ditentukan oleh situs insersi transgen dalam genom tanaman. Selain itu, galur 4.2 .3 (fusi) dan galur 3R9 (mpi) mempunyai toksisitas moderat. Hal ini terbukti menunjukkan bahwa mortalitas 50\% larva instar-1 $S$. incertulas pada galur 4.2 .3 (fusi) dan galur 3R9 (mpi) tercapai dalam waktu 24 jam setelah infestasi dan pada 72 jam setelah infestasi mortalitasnya masing-masing mencapai $74.5 \%$ dan $73.5 \%$ (Usyati et al, 2010 in press)

Padi transgenik galur DT-cry masuk kategori rentan dengan nilai ketahanan pada skala 7. Hal ini disebabkan jumlah salinan gen (copy number) yang sedikit (Tabel 4) dan situs insersi gen kurang tepat dalam genom tanaman. Dengan jumlah salinan gen (copy number) yang sedikit kemungkinan ekspresi protein menjadi lebih rendah. Sementara situs insersi gen yang kurang tepat dapat menyebabkan gen kurang terekspresi. 
Tabel 4. Jumlah salinan gen (copy number) pada berbagai perlakuan

\begin{tabular}{lcl}
\hline \multicolumn{1}{c}{ Perlakuan } & $\begin{array}{c}\text { Jumlah salinan gen (copy } \\
\text { number })\end{array}$ & \multicolumn{1}{c}{ Sumber } \\
\hline $\begin{array}{l}\text { Galur fusi dua gen } \\
\text { (cryIB-cryIAa) }\end{array}$ & $1-6$ & Rahmawati (2004) \\
Galur $m p i-$ cryIB & $3-6$ & Rachmat et al. (2007) \\
Galur 6.11 & $1-10$ & Satoto (2003) \\
Galur DT cry & $1-2$ & Rachmat (2006) \\
\hline
\end{tabular}

Selain itu, galur DT-cry jumlah salinan gen (copy number) mempunyai toksisitas yang rendah. yang berbeda (Tabel 4), posisi Hal ini terbukti pada pengamtan integrasi atau situs insersi gen dalam mortalitas serangga di cawan petri genom tanaman, dan tingkat toksisitas yang menunjukkan bahwa mortalitas yang berbeda. Perbedaan jumlah 50\% larva instar-1 S. incertulas pada salinan gen (copy number) pada kedua galur DT-cry tercapai dalam waktu 48 galur tersebut disebabkan oleh jam setelah infestasi dan pada 72 jam perbedaan teknik transformasi. Galur setelah infestasi mortalitasnya hanya 6.11 teknik transformasinya melalui mencapai 69.5\% (Usyati et al., 2010 in penembakan dan galur DT-cry melalui press). Selain itu diduga hal ini Agrobacterium. Teknik transformasi disebabkan oleh generasi galur DT-cry genetika melalui penembakan pada ini masih generasi awal yaitu generasi umumnya menghasilkan tanaman ke-2. Menurut Meyer (1995) uji transgenik dengan salinan transgen ketahanan galur padi transgenik pada ganda yang sangat banyak (Vain et al. generasi awal mempunyai kelemahan 2002). Sementara teknik transformasi yaitu pada umumnya pada tanaman transgenik generasi 2-3 masih terdapat keragaman antar tanaman yang sangat besar.

Padi transgenik galur 6.11 dan galur DT-cry sama mengandung gen cryIAb, namun kedua galur tersebut mempunyai nilai ketahanan yang berbeda. Galur 6.11 mempunyai nilai ketahanan tertinggi dengan skala 0 sementara galur DT-cry masuk kategori rentan dengan nilai ketahanan pada skala 7. Adanya perbedaan ini kemungkinan disebabkan oleh faktor genetika melalui Agrobacterium pada umumnya menghasilkan tanaman transgenik dengan salinan transgen yang relatif sedikit (Maftuchah 2003).

Padi transgenik galur DT-cry (Azygous) masuk kategori rentan dengan nilai ketahanan pada skala 9. Hal ini disebabkan galur DT-cry (Azygous) hanya ikut dalam transformasi tetapi tidak mengandung gen cry (null). Dengan demikian sumber ketahanan intrinsik pada galur DT-cry (Azygous) ini bukan toxin, tetapi sama dengan padi bukan 
transgenik yaitu berasal dari karakteristik biokimia dan karakteristik biofisik tanaman (Kogan 1982).

\section{KESIMPULAN}

Semua galur padi transgenik, kecuali galur DT-cry dan DT-cry (Azygous), lebih efektif dalam menangkal kerusakan dan menghambat pertumbuhan hama $S$. incertulas serta mempunyai nilai ketahanan yang tinggi dibandingkan dengan varietas padi bukan transgenik. Ada perbedaan nilai ketahanan antar galur padi transgenik. Padi transgenik galur 6.11 mempunyai nilai ketahanan tertinggi dengan skala 0. Galur 4.2.4 (fusi) dan 3R7 (mpi) mempunyai nilai ketahanan pada skala 1. Sementara galur 4.2.3 (fusi) dan galur 3R9 (mpi) mempunyai nilai ketahanan pada skala 3. Galur DT-cry dan DT-cry (Azygous) masuk kategori rentan dengan nilai ketahanan masing-masing pada skala 7 dan 9 .

\section{UCAPAN TERIMA KASIH}

Terima kasih disampaikan kepada tim peneliti dan teknisi Biologi Molekuler Tanaman, Pusat Penelitian Bioteknologi-LIPI, Cibinong-Bogor yang telah membantu dana, materi, dan fasilitas penelitian, serta membantu kelancaran penelitian di rumah kaca. Terima kasih juga disampaikan kepada tim peneliti dan teknisi Kelti Entomologi-Fitopatologi Balai Besar Penelitian Tanaman Padi Sukamandi-
Subang yang telah membantu pemeliharaan serangga uji.

\section{DAFTAR PUSTAKA}

Bahagiawati. 2001. Manajemen resistensi serangga hama pada pertanaman tanaman transgenik Bt. Buletin AgroBio 4(1):1-8.

Cohen MB. 2000. Bt rice: practical steps to sustainable use. International Rice Research Notes 25(2):4-10.

Datta K et al., 1998. Constitutive and tissue-specific differential expression of the cryIA(b) gene in transgenic rice plants conferring resistance to rice insect pest. Theor Appl Genet 97:20-30.

Fontes EMG et al., 2002. The environmental effects of genetically modified crops resistant to insect. Neotropical Entomology 31(4):497-513.

Heinrich EA, Medrano FG, Rapusas HR. 1985. Genetic Evaluation for Insect Resistance in Rice. Los Banos, Philippines: Intl Rice Res Inst. p 356.

Ho NH et al., 2006. Translational fusion hybrid $B t$ genes confer resistance against yellow stem borer in transgenic elite vietnamese rice (Oryza sativa L.) cultivars. Crop Sci 46:781789.

Kogan M. 1982. Plant resistance in pest management. In: Metcalf RL, WH Luckmann, editor. Introduction to Insect Pest Management. Second Edition. 
New York: John Wiley and Sons. pp 93-134.

Maftuchah. 2003. Transformasi genetik padi indica dengan gen cryIA(b) dan cryIB menggunakan Agrobacterium tumefaciens untuk ketahanan terhadap hama penggerek batang kuning (Scirpophaga incertulas Walker) [disertasi). Bogor: Program Pascasarjana, Institut Pertanian Bogor.

Meyer P. 1995. Understanding and controlling transgene expression. TibTech 13:332337.

Rachmat A. 2006. Konstruksi vektor ekspresi gen untuk mengeliminasi gen penyeleksi antibiotik pada tanaman padi (Oryza sativa L.) transgenik [tesis]. Bogor: Program Pascasarjana, Institut Pertanian Bogor.

Rachmat S et al., 2007. Aplikasi teknologi DNA untuk ketahanan terhadap hama penggerek batang padi serta uji keamanan lingkungan [laporan teknik]. Bogor: Pusat Penelitian Bioteknologi Lembaga Ilmu Pengetahuan Indonesia. hal.67-73.

Rahmawati S. 2004. Introduksi dua gen cry dengan "binding site" berbeda dan penggunaan promoter terinduksi pelukaan pada padi (Oryza sativa L) untuk memperlama ketahanan [laporan riset unggulan terpadu bidang pertanian dan pangan]. Bogor: Kementerian Riset dan Teknologi RI Lembaga Ilmu
Pengetahuan Indonesia. 50 hlm.

SAS Institute. 1990. SAS/STAT User's Guide, Version 6. Fourth Edition. Volume 2. North Carolina: SAS Institute Inc.

Satoto. 2003. Kestabilan, pola pewarisan, dan keefektifan gen gna dan cry $1 \mathrm{Ab}$ terhadap wereng batang coklat dan penggerek batang kuning pada padi rojolele transgenik [disertasi]. Bogor: Program Pascasarjana, Institut Pertanian Bogor.

Usyati N, Buchori D, Manuwoto S, Hidayat P, Loedin IHS. 2010. Efektivitas galur padi Rojolele transgenik terhadap hama penggerekbatang padi kuning Scirpophaga incertulas (Walker) (Lepidoptra: Pyralidae) pada tahap in vitro. Jurnal Penelitian Pertanian Tanaman Pangan (in press).

Schuler TH. 2000. The impact of insect resistant GM crops on populations of natural enemies. Antenna 24:59-65.

Vain P, James VA, Worland B, Snape JW. 2002. Transgene behaviour across two generations in a large random population of transgenic rice plants produced by particle bombardment. Theor Appl Genet 105:878-889.

Wu C, Fan Y, Zhang C, Oliva N, Datta SK. 1997. Transgenic fertile japonica rice plants expressing a modified cryIA(b) gene resistant to yellow stem borer. Plant Cell Reports 17:129-132. 
N. Usyati et al.,: Keefektivan Padi Transgenik

Ye GY, Tu J, Hu C, Datta K, Datta SK. 2001. Transgenic IR72 with fused Bt gene cry $1 \mathrm{~A}(\mathrm{~b}) /$ cry $1 \mathrm{~A}(\mathrm{c}) \quad$ from Bacillus thuringiensis is resistant against four lepidoptera species under field condition. Plant Biotechnol 18:125-133. 